\title{
EFFECTS OF THE GENERIC NATURE OF POLYMERS ON THEIR FIRE BEHAVIOR
}

\author{
G. Marlair \\ INERIS, Accidental Risks Division \\ Parc technologique ALATA, BP n², 60550 Verneuil-en Halatte, France \\ (Guy.marlair@ineris.fr)
}

\author{
A. Tewarson \\ FM Global Research \\ 1151 Boston-Providence Turnpike, Norwood, MA 02062, USA \\ (Archibald.Tewarson@fmglobal.com)
}

\begin{abstract}
Fire behavior of four aliphatic and two aromatic $\mathrm{C}, \mathrm{H}, \mathrm{O}, \mathrm{N}, \mathrm{S}$, and $\mathrm{Cl}$ atom containing polymers has been examined. Experiments were performed in three ASTM E 2058 Fire Propagation Apparatuses. The differences in the ignition behavior of polymers were found to be mainly due to differences in the ignition temperature. Chemical effects appear to contribute about $25 \%$ towards the ignition resistance of the polymers. For thermoplastics, formation of polymer melt and its burning as a pool fire was found to increase the fire intensity by factors of two to four. The combustion efficiency and generation efficiency of $\mathrm{CO}_{2}$ were found to decrease and the generation efficiencies of $\mathrm{CO}$ and smoke were found to increase by changes in the generic nature of the polymers (aliphatic to aromatic to halogenated). About four times as much carbon atoms in the polymers converted to smoke than converted to $\mathrm{CO}$. Large-scale fire propagation behavior of polymers was characterized by a Fire Propagation Index (FPI). The FPI values of melting type thermoplastics (showing rapid-fire propagation behavior) were high, whereas they were low for the engineered charring type and halogenated polymers (showing either slow or decelerating fire propagation behavior).
\end{abstract}

KEYWORDS: flammability, fire properties, ignition, combustion, and fire propagation

\section{INTRODUCTION}

Polymers are macromolecular organic materials manufactured by the modification of natural products or by synthesis from suitable intermediates. The number of basic polymers is large, the list is growing, and variations and modifications to these basic polymers, and co-polymers are quite large. Almost all the polymers consist of hydrogen, oxygen, nitrogen, sulfur, chlorine, fluorine, and silicone atoms bonded alone or in combination with other atoms to the polymer backbone of carbon atoms with different types of chemical bonding. Polymers can be predominantly crystalline, amorphous or a combination of both the natures. In predominantly crystalline polymers, chains are packed together more efficiently and tightly than in the amorphous polymers [1]. Polymers with higher crystallinity have higher thermal stability than amorphous polymers. All these differences are reflected in wide variations in the fire behavior of polymers.

In our study, we have attempted to examine the differences in the fire behavior of polymers because of variations in their generic nature and physical and chemical properties. Four aliphatic and two aromatic polymers with $\mathrm{H}, \mathrm{O}, \mathrm{N}, \mathrm{S}$, and $\mathrm{Cl}$ atoms bonded to the polymer backbone of $\mathrm{C}$ atoms were examined. Independent experiments 
were performed in the three ASTM E 2058 Fire Propagation Apparatuses [2], one at INERIS, one at FM Global Research (FMR) and one at FM Approvals.

\section{EXPERIMENTAL}

\section{POLYMERS USED IN THE STUDY}

The following polymers were examined as sheets from original resins, without any additives, except those used for processing:

1. Polyoxymethylene, POM (aliphatic: C, H, O atoms, $\mathrm{M}_{\text {mono }}: 29 \mathrm{~g} / \mathrm{mole}$, melting type);

2. Poly(methylmethacrylate), PMMA (aliphatic: $\mathrm{C}, \mathrm{H}, \mathrm{O}$ atoms; $\mathrm{M}_{\text {mono }}: 100 \mathrm{~g} / \mathrm{mole}$, melting type);

3. Nylon 6,6 (aliphatic: $\mathrm{C}, \mathrm{H}, \mathrm{O}, \mathrm{N}$ atoms; $\mathrm{M}_{\text {mono }}: 226 \mathrm{~g} / \mathrm{mole}$, melting type);

4. Poly(vinylchloride), PVC, rigid (aliphatic: $\mathrm{C}, \mathrm{H}, \mathrm{Cl}$ atoms; $\mathrm{M}_{\text {mono }}: 62 \mathrm{~g} / \mathrm{mole}$, charring type),

5. Polycarbonate, $\mathrm{PC}$ (aromatic: $\mathrm{C}, \mathrm{H}, \mathrm{O}$ atoms; $\mathrm{M}_{\text {mono }}: 238 \mathrm{~g} / \mathrm{mole}$, charring type);

6. Polysulfone, PSF (aromatic: $\mathrm{C}, \mathrm{H}, \mathrm{O}, \mathrm{S}$ atoms; $\mathrm{M}_{\text {mono }}: 442 \mathrm{~g} / \mathrm{mole}$, charring type).

The measured elemental composition and net heat of complete combustion are listed in Table 1 . The data indicate that the resins are relatively pure with negligible amounts of impurities or additives. Additional information on the polymer samples, data analysis and experimental facilities are described in Ref [3]. For the analysis of experimental results, these data along with the literature data listed in Table 2 were used.

Table 1: Measured Elemental Composition and Net Heat of Complete Combustion of Polymers

\begin{tabular}{|c|c|c|c|c|c|c|c|}
\hline \multirow{2}{*}{ Polymer } & \multicolumn{6}{|c|}{ Elemental Composition (\% Weight) } & \multirow{2}{*}{$\begin{array}{c}\Delta \mathbf{H}_{\mathrm{T}} \\
\mathbf{M J} / \mathbf{k g}\end{array}$} \\
\hline & $\mathbf{C}$ & $\mathbf{H}$ & $\mathbf{O}$ & $\mathbf{N}$ & $\mathbf{S}$ & $\mathbf{C l}$ & \\
\hline POM & 41.40 & 6.91 & 51.40 & 0.15 & $<0.04$ & $<0.02$ & 15.7 \\
\hline PMMA & 60.10 & 8.56 & 32.14 & $<0.1$ & $<0.04$ & $<0.02$ & 24.8 \\
\hline Nylon 6,6 & 61.86 & 10.25 & 17.82 & 11.98 & $<0.02$ & $<0.02$ & 29.2 \\
\hline PVC (rigid) & 38.90 & 4.77 & 4.33 & $<0.1$ & 0.36 & 49.00 & 19.3 \\
\hline $\mathrm{PC}$ & 75.70 & 5.50 & 18.40 & $<0.1$ & $<0.04$ & $<0.02$ & 29.9 \\
\hline PSF & 72.90 & 4.82 & 14.39 & $<0.1$ & 8.2 & 0.02 & 30.4 \\
\hline
\end{tabular}

Table 2: Thermophysical Properties of Polymers from the Literature ${ }^{a}$

\begin{tabular}{|c|c|c|c|c|}
\hline Polymers & $\begin{array}{c}\mathrm{k} \times 10^{3} \\
(\mathrm{~kW} / \mathrm{m}-\mathrm{K})\end{array}$ & $\begin{array}{l}\rho \times 10^{-3} \\
\left(\mathrm{~kg} / \mathrm{m}^{3}\right)\end{array}$ & $\begin{array}{c}c \\
(\mathrm{~kJ} / \mathrm{kg}-\mathrm{K})\end{array}$ & $\begin{array}{c}\Delta \mathbf{H}_{\mathrm{ch}} / \Delta \mathbf{H}_{\mathrm{g}} \\
(\mathbf{M J} / \mathbf{M J})\end{array}$ \\
\hline POM & 0.28 & 1.42 & 1.46 & 6 \\
\hline PMMA & 0.18 & 1.19 & 1.47 & 17 \\
\hline Nylon 6,6 & 0.23 & 1.14 & 1.70 & 12 \\
\hline PVC (rigid) & 0.25 & 1.38 & 1.41 & 2 \\
\hline $\mathrm{PC}$ & 0.21 & 1.20 & 1.17 & 7 \\
\hline PSF & 0.28 & 1.24 & 1.30 & 5 \\
\hline
\end{tabular}

a: data are taken from Refs. 1,4,5,6,7, 8 and 9 . 


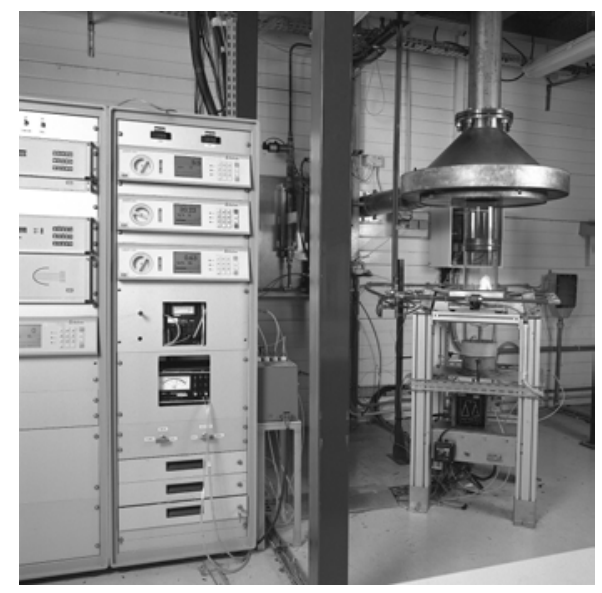

Figure 1. ASTM E 2058 Apparatus at INERIS [2]

One of the three ASTM E 2058 Fire Propagation Apparatuses used in this study is shown in Fig. 1. Three types of experiments were performed: 1) ignition, 2) combustion, and 3) fire propagation. For ignition and combustion experiments, $100-\mathrm{mm}$ square and $10-\mathrm{mm}$ thick horizontal sheets were used. The sample surface was painted black. For fire propagation experiments, 300-mm long, $100-\mathrm{mm}$ wide and $10-\mathrm{mm}$ thick vertical sheets were used. The sides and back of all the samples were tightly covered with ceramic paper and aluminum foil as described in the ASTM E 2058 standard. Cross wires across the surfaces were used for all the samples, because some of the samples expanded when exposed to external heat flux due to charring.

Ignition experiments were performed under quiescent normal airflow condition with a small pilot flame close to the surface. The entire sample surface was exposed to external heat flux in the range of 10 to $60 \mathrm{~kW} / \mathrm{m}^{2}$. Combustion experiments were performed under co-normal airflow rate of $158-\mathrm{mm} / \mathrm{s}$ (volumetric flow rate of $2.9 \times 10^{-3} \mathrm{~m}^{3} / \mathrm{s}$ ) with entire surface exposed to $50 \mathrm{~kW} / \mathrm{m}^{2}$ of external heat flux. The fire propagation experiments were performed in $40 \%$ oxygen concentration in the co-air-oxygen mixture flowing at a rate of $158-\mathrm{mm} / \mathrm{s}$ (volumetric flow rate of $2.9 \times 10^{-3} \mathrm{~m}^{3} / \mathrm{s}$ ). Only the $120-\mathrm{mm}$ bottom part of the sample was exposed to $50 \mathrm{~kW} / \mathrm{m}^{2}$ of external heat flux in the presence of a pilot flame in the fire propagation experiments.

In the ignition experiments, ignition-time was measured as a function of the external heat flux. In the combustion and fire propagation experiments, measurements were made for the release rates of polymers vapors, heat, and products.

\section{IGNITION}

In the experiments, ignition-time, defined as the appearance of a sustained flame, was measured visually by a stopwatch. The measured ignition-time at each flux from the three laboratories varied between 3 to $15 \%$ of the average value for the non-charring and nonexpanding POM, PMMA, and nylon and between 4 to $31 \%$ of the average value for the charring and expanding PC, PSF, and PVC. The variations were higher at lower heat fluxes than for heat fluxes $\geq 30 \mathrm{~kW} / \mathrm{m}^{2}$, where the variations were only between 3 to $10 \%$ of the average value for all the polymers, a range used to obtain the ignition properties of the polymers.

The ignition-time and external heat flux relationship shown in Fig. 2 for POM is very similar for all the polymers and has been analyzed using the following well known relationship for thermally thick conditions [10]:

$$
1 / t_{\mathrm{ig}}^{1 / 2}=\left(\dot{\mathbf{q}}_{\mathrm{e}}^{\prime \prime}-\dot{\mathbf{q}}_{\mathrm{cr}}^{\prime \prime}\right) /\left(\mathrm{T}_{\mathrm{ig}}-\mathrm{T}_{\mathrm{a}}\right) \sqrt{\mathrm{k \rho c}}
$$


The term $\left(\mathbf{T}_{\mathbf{i g}}-\mathbf{T}_{\mathbf{a}}\right) \sqrt{\mathbf{k \rho c}}$ is defined as the Thermal Response Parameter (TRP) of the polymer [8]. $\dot{\mathbf{q}}_{\mathbf{c r}}$ is the minimum heat flux at or below there is no sustained ignition, which is about $10 \mathrm{~kW} / \mathrm{m}^{2}$ in Fig. 2. The TRP value is derived from the inverse of the slope in the range of $\dot{\mathbf{q}}_{\mathbf{e}}^{\prime \prime} \geq 30 \mathrm{~kW} / \mathrm{m}^{2} . \quad \dot{\mathbf{q}}_{\mathbf{c r}}^{\prime \prime}$ and TRP values derived in this fashion are listed in Table 3.

The TRP values from the three laboratories vary between 6 to $11 \%$ of the average value. There is no variation in the $\dot{\mathbf{q}}_{\mathbf{c r}}$ values. The values are lower for the aliphatic polymers compared to the aromatic and aliphatic halogenated polymers.

Data in Table 3 and for many polymers listed in the literature $[1,4,5,6,7]$ show that the $\sqrt{\mathbf{k \rho c}}$ component of TRP is approximately constant with an average value of $0.72 \pm 19 \%$. The differences in the TRP values in Table 3 thus are mainly due to the differences in the $\mathbf{T}_{\mathbf{i g}}$ values. This is supported by the estimated ${ }^{1} \sqrt{\mathbf{k \rho \mathbf { c }}}$ values also listed in Table 3, which are very similar to the calculated $\sqrt{\mathbf{k} \rho \mathbf{c}}$ values. The $\mathbf{T}_{\mathbf{i g}}$ values of polymers depend on the chemical bond dissociation energies and generic nature of the polymer vapor in addition to thermal effects [9,11]. For ordinary polymers, $\mathbf{T}_{\mathbf{i g}} \approx$ vaporization $\left(\mathbf{T}_{\mathbf{v}}\right)$ or decomposition temperature $\left(\mathbf{T}_{\mathbf{d}}\right)$, which supports the influence of the bond dissociation energy on the ignition behavior $[9,11]$. For high temperature and highly halogenated advanced engineered polymers, $\mathbf{T}_{\mathbf{i g}} \gg \mathbf{T}_{\mathbf{v}} / \mathbf{T}_{\mathbf{d}}$ suggesting the influence of both bond dissociation energy as well as of the generic nature of the polymer vapors

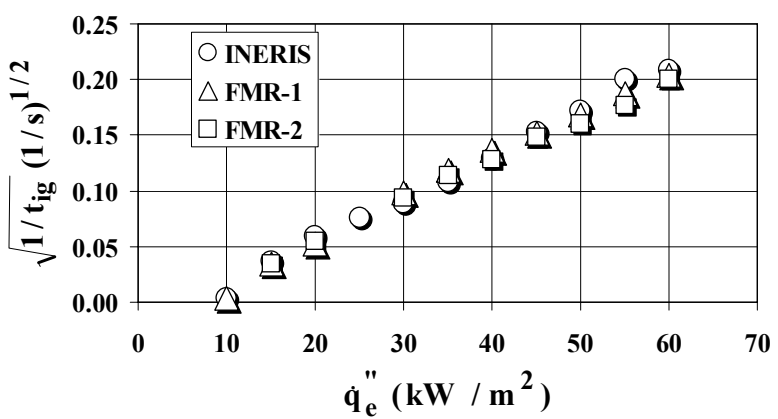

Figure 2. Ignition-time versus external heat flux (Eq. 1) from the ignition data for POM measured in the ASTM E 2058 apparatuses. FMR: FM Global Research. $[9,11]$. It is estimated that chemical factors contribute to some $25 \%$ in the TRP value [9].

It is, therefore, necessary to account for factors such as energies associated with chemical bonds and chemical nature of the vapors in addition to thermal effects to describe the ignition behavior of polymers.

1 The $\sqrt{\mathbf{k} \rho \mathbf{c}}$ values of polymers were estimated from the expression: $\sqrt{\mathbf{k} \rho \mathbf{c}}=\operatorname{TRP} /\left[\left\{\left(\dot{\mathbf{q}}_{\mathrm{cr}}\right)^{\mathbf{0 . 2 5}} \times \mathbf{3 6 4}\right\}-\mathbf{2 9 3}\right]$, where it is assumed that heat losses are mainly due to surface reradiation, polymer surface acts as a black body and the ambient temperature is $20^{\circ} \mathrm{C}$. 


\section{COMBUSTION}

In the experiments, release rates of polymer vapors, heat, and fire products were determined ${ }^{2}$. In the experiments at $50 \mathrm{~kW} / \mathrm{m}^{2}$, the $10-\mathrm{mm}$ thick melting type polymers (POM, PMMA, and nylon) burned as liquid pool fires, whereas the $10-\mathrm{mm}$ thick charring type polymers (PVC, PC, and PSF) burned as solid polymers. Thus, the data for POM, PMMA, and nylon are for the combustion of polymer melts whereas the data for PVC, PC, and PSF are for the combustion of solid polymers.

Table 3. Ignition Properties of Polymers

\begin{tabular}{|c|c|c|c|c|c|}
\hline \multirow[b]{2}{*}{ Polymer } & \multirow[b]{2}{*}{ Lab } & \multirow{2}{*}{$\begin{array}{c}\text { TRP }(k W- \\
\left.\mathbf{s}^{1 / 2} / \mathbf{m}^{2}\right)\end{array}$} & \multirow{2}{*}{$\underset{\left(\mathbf{k W} / \mathbf{m}^{2}\right)}{\dot{\mathbf{q}}_{\mathrm{cr}}^{\prime \prime}}$} & \multicolumn{2}{|c|}{$(\mathrm{k} \rho \mathrm{c})^{1 / 2}\left(\mathrm{kw}-\mathrm{s}^{1 / 2} / \mathrm{m}^{2}-\mathrm{K}\right)$} \\
\hline & & & & $\begin{array}{r}\text { From } \\
\text { Table } 2\end{array}$ & Estimated \\
\hline \multirow{4}{*}{$\begin{array}{l}\text { POM (aliphatic } \\
\text { C,H,O atoms) }\end{array}$} & INERIS & 238 & \multirow{4}{*}{10} & \multirow{3}{*}{0.76} & 0.67 \\
\hline & FMR-1 & 286 & & & 0.81 \\
\hline & FMR-2 & 294 & & & 0.83 \\
\hline & Average & $204 \pm 11 \%$ & & Average & 0.77 \\
\hline \multirow{4}{*}{$\begin{array}{l}\text { PMMA } \\
\text { (aliphatic } \\
\text { C,H,O atoms) }\end{array}$} & INERIS & 200 & \multirow{4}{*}{10} & \multirow{3}{*}{0.56} & 0.56 \\
\hline & FMR-1 & 196 & & & 0.55 \\
\hline & FMR-2 & 217 & & & 0.61 \\
\hline & Average & $204 \pm 6 \%$ & & Average & 0.58 \\
\hline \multirow{4}{*}{$\begin{array}{l}\text { Nylon 6,6 } \\
\text { (aliphatic } \\
\text { C,H,O,N } \\
\text { atoms) }\end{array}$} & INERIS & 263 & \multirow{4}{*}{15} & \multirow{3}{*}{0.67} & 0.62 \\
\hline & FMR-1 & 244 & & & 0.58 \\
\hline & FMR-2 & 278 & & & 0.66 \\
\hline & Average & $262 \pm 6 \%$ & & Average & 0.62 \\
\hline \multirow{3}{*}{$\begin{array}{l}\mathrm{PC} \text { (aromatic } \\
\mathrm{C}, \mathrm{H}, \mathrm{O} \text { atoms) }\end{array}$} & INERIS & 323 & \multirow{3}{*}{25} & \multirow{2}{*}{0.54} & 0.62 \\
\hline & FMR-1 & 313 & & & 0.60 \\
\hline & Average & 318 & & Average & 0.61 \\
\hline \multirow{4}{*}{$\begin{array}{l}\text { PSF (aromatic } \\
\text { C,H,O,S atoms) }\end{array}$} & INERIS & 333 & \multirow{4}{*}{30} & \multirow{3}{*}{0.67} & 0.60 \\
\hline & FMR-1 & 357 & & & 0.64 \\
\hline & FMR-2 & 313 & & & 0.56 \\
\hline & Average & $334 \pm 7 \%$ & & Average & 0.60 \\
\hline \multirow{4}{*}{$\begin{array}{l}\text { PVC (aliphatic } \\
\text { C,H,Cl atoms) }\end{array}$} & INERIS & 333 & \multirow{4}{*}{15} & \multirow{3}{*}{0.70} & 0.79 \\
\hline & FMR-1 & 357 & & & 0.85 \\
\hline & FMR-2 & 385 & & & 0.91 \\
\hline & Average & $358 \pm 7 \%$ & & Average & 0.85 \\
\hline
\end{tabular}

The polymer vapors, heat and product release rate profiles and steady state (maximum) values from the three laboratories were in excellent agreement, such as shown by the data in Fig. 3 for the heat release profiles for POM and by the steady state data in Table $4^{3,4}$.

${ }^{2}$ For heat release rate from the Oxygen Consumption and Carbon Dioxide Generation Calorimetries, net heat of complete combustion per unit mass of oxygen consumed and $\mathrm{CO}$ and $\mathrm{CO}_{2}$ generated were obtained from the data in Table 1.

${ }^{3}$ Combustion efficiency $(\chi)$ is defined as the ratio of the chemical (actual) heat of combustion to the net heat of complete combustion [8]. 


\section{Release Rates of Polymer Vapors, Heat, and Products}

For the combustion experiments at $\dot{\mathbf{q}}_{\mathrm{e}}^{\prime \prime}=50 \mathrm{~kW} / \mathrm{m}^{2}$, the release rates of polymer vapors, heat, and products can be expressed as:

$$
\begin{aligned}
& \dot{\mathbf{m}}^{\prime \prime}=\left(\dot{\mathbf{q}}_{\mathrm{e}}^{\prime \prime}+\dot{\mathbf{q}}_{\mathrm{f}}^{\prime \prime}-\dot{\mathbf{q}}_{\mathrm{rr}}^{\prime \prime}\right) / \Delta \mathbf{H}_{\mathrm{g}} \\
& \dot{\mathbf{Q}}_{\mathrm{ch}}^{\prime \prime}=\left(\Delta \mathbf{H}_{\mathrm{ch}} / \Delta \mathbf{H}_{\mathrm{g}}\right)\left(\dot{\mathbf{q}}_{\mathrm{e}}^{\prime \prime}+\dot{\mathbf{q}}_{\mathrm{f}}^{\prime \prime}-\dot{\mathbf{q}}_{\mathrm{rr}}^{\prime \prime}\right)=\chi\left(\Delta \mathbf{H}_{\mathrm{T}} / \Delta \mathbf{H}_{\mathrm{g}}\right)\left(\dot{\mathbf{q}}_{\mathrm{e}}^{\prime \prime}+\dot{\mathbf{q}}_{\mathrm{f}}^{\prime \prime}-\dot{\mathbf{q}}_{\mathrm{rr}}^{\prime \prime}\right) \\
& \dot{\mathbf{G}}_{\mathrm{j}}^{\prime \prime}=\left(\mathbf{y}_{\mathrm{j}} / \Delta \mathbf{H}_{\mathrm{g}}\right)\left(\dot{\mathbf{q}}_{\mathrm{e}}^{\prime \prime}+\dot{\mathbf{q}}_{\mathrm{f}}^{\prime \prime}-\dot{\mathbf{q}}_{\mathrm{rr}}^{\prime \prime}\right)=\mathbf{f}_{\mathrm{j}}\left(\Psi_{\mathrm{j}} / \Delta \mathbf{H}_{\mathrm{g}}\right)\left(\dot{\mathbf{q}}_{\mathrm{e}}^{\prime \prime}+\dot{\mathbf{q}}_{\mathrm{f}}^{\prime \prime}-\dot{\mathbf{q}}_{\mathrm{rr}}^{\prime \prime}\right)
\end{aligned}
$$

In the combustion experiments, flames were completely lifted off the surface due to high release rate of polymer vapors. Under this

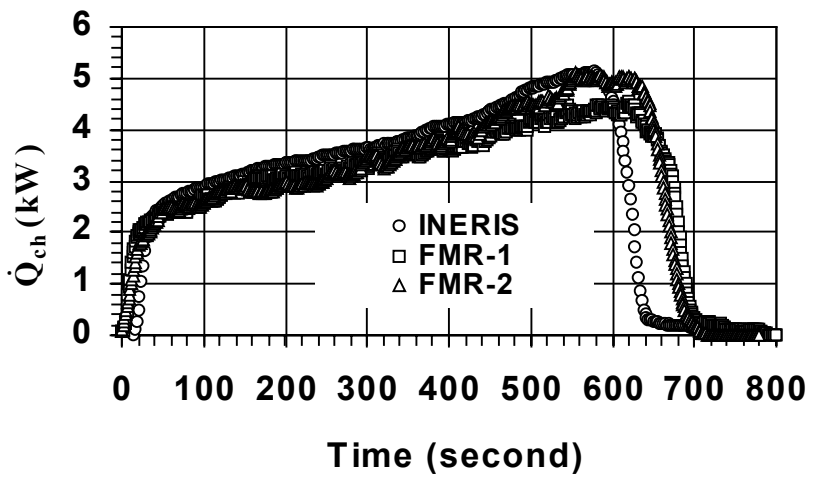

Figure 3. Heat release rate in the combustion of POM in normal air at $50 \mathrm{~kW} / \mathrm{m}^{2}$ in the ASTM E 2058 apparatuses. condition, $\dot{\mathbf{q}}_{\mathrm{f}}^{\prime \prime}$ value can be assumed negligibly small and $\dot{\mathbf{m}}$ " values can be predicted from $\Delta \mathbf{H}_{\mathrm{ch}} / \Delta \mathbf{H}_{\mathrm{g}} \quad$ and $\quad \dot{\mathbf{q}}_{\mathrm{rr}}^{\prime \prime}$ values. Assuming $\dot{\mathbf{q}}_{\mathbf{f}}^{\prime \prime}=$ 0 , the predicted m" values for ordinary polymers are in the range of about 20 to $30 \times 10^{-3}$ $\mathrm{kg} / \mathrm{m}^{2}$-s for $\dot{\mathbf{q}}_{\mathbf{e}}^{\prime \prime}=50$ $\mathrm{kW} / \mathrm{m}^{2}$. The measured range of $\dot{\mathbf{m}} "$ values in Table 4 for the three charring type polymers (PVC, PC, and PSF) is similar to the predicted range. The measured range for $\dot{\mathbf{m}}$ "values for melting type polymers (POM, PMMA, and nylon), however, is significantly higher than the predicted range for the solid polymers, but similar to that for the generic similar liquids. For example, the predicted $\dot{\mathbf{m}}$ "values are $50,55,93 \times 10^{-3} \mathrm{~kg} / \mathrm{m}^{2}$-s for methanol, hexadecane, and butanol respectively at $50 \mathrm{~kW} / \mathrm{m}^{2}[12]$.

The measured range of $\dot{\mathbf{m}}$ " values for the melting type polymers (POM, PMMA, and nylon) are similar to the predicted $\dot{\mathbf{m}} "$ range at $50 \mathrm{~kW} / \mathrm{m}^{2}$ for generically similar liquids. These observations suggest that formation, flow, and burning of polymer melt as liquid pool fires are critical stages in fires in thermoplastics (thickness $\leq 10$-mm for $\dot{\mathbf{q}}_{\mathrm{e}} \geq$ $50 \mathrm{~kW} / \mathrm{m}^{2}$ ). The importance of these behaviors was also found critical in large-scale fires of 3 to 5 -mm thick polymer parts of a minivan [13].

${ }^{4}$ Generation efficiency $\left(\mathbf{f}_{\mathbf{j}}\right)$ of a product is defined as the ratio of the yield of the product to its maximum possible stoichiometric yield based on its elemental composition [8]. For example for the calculation of the maximum possible stoichiometric yield of $\mathrm{CO}$, it is assumed that in the combustion all the carbon atoms in the polymer are completely converted to only CO. 


\section{Combustion Efficiency and Generation Efficiency of Products}

Data in Table 4 and Figs. 4 and 5 indicate that $\chi \approx \mathbf{f}_{\mathrm{CO} 2}$, that these two parameters are inversely proportional to $\mathbf{f}_{\mathrm{CO}}$ and $\mathbf{f}_{\mathrm{sm}}$ and that there is a linear relationship between $\mathbf{f}_{\mathrm{Co}}$ and $\mathbf{f}_{\mathrm{sm}}$. The data also show that $\chi$ and $\mathbf{f}_{\mathrm{CO} 2}$ decrease and $\mathbf{f}_{\mathrm{CO}}$ and $\mathbf{f}_{\mathrm{sm}}$ increase as the generic

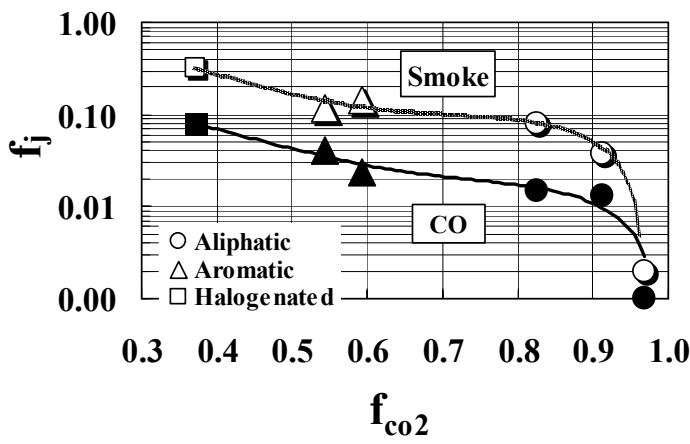

Figure 4. Generation efficiencies of $\mathrm{CO}$ and smoke versus $\mathrm{CO}_{2}$ efficiency for the well-ventilated combustion of polymers.

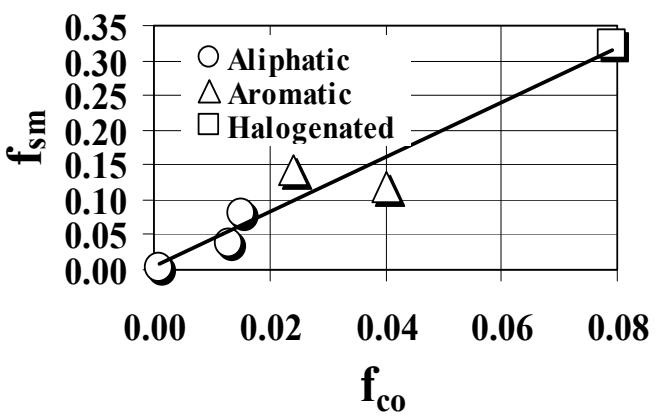

Figure 5. Generation efficiency of smoke versus $\mathrm{CO}$ efficiency for the wellventilated combustion of polymers.

nature of the polymers changes from aliphatic to aromatic to halogenated. About four times as much carbon atoms are converted to smoke compared to the conversion to $\mathrm{CO}$. Molecular weight of the monomer appears to have a stronger effect on the $\chi, \mathbf{f}_{\mathbf{C O}}$, and $\mathbf{f}_{\mathrm{sm}}$ values than the generic nature of the atoms in the structure. The implications of variations in the $\chi, \mathbf{f}_{\mathrm{CO} 2}, \mathbf{f}_{\mathrm{CO}}$ and $\mathbf{f}_{\mathrm{sm}}$ values are reflected in the expressions for the release rates of heat and products in Eqs. 3 and 4.

\section{FIRE PROPAGATION}

Vertical fire propagation experiments were performed in $40 \%$ oxygen concentration, with bottom $30 \%$ of length exposed to $50 \mathrm{~kW} / \mathrm{m}^{2}$ in the presence of a pilot flame. The $40 \%$ oxygen concentration simulates flame radiative heat flux transferred to the surface in large-scale fires [14]. The fire propagation experiments thus are simulation of large-scale upward fire propagation.

In the experiments release rates of heat and products during upward fire propagation and initial and final weight of the sample were measured. Fire propagation was very rapid for POM and PMMA, but was slow for PVC, PC, and PSF. Fire propagation experiments could be not be performed for nylon 6,6 due to rapid melting. The heat and product release rate profiles during fire propagation, from the three laboratories, were in excellent agreement, as shown in Fig. 6 for PMMA.

For examining the upward fire propagation behavior of polymers, theoretical expression for the flame spread velocity $[10,15]$ was utilized. With an assumption that the forward heat transfer from the leading edge of the flame is proportional to $(\dot{\mathbf{Q}} / \mathbf{w})^{\mathbf{n}}$, flame spread theories [15] suggest the following expression for the upward fire propagation velocity:

$$
\mathbf{v}^{1 / 2} \propto\left(\dot{Q}_{\mathrm{r}} / \mathrm{w}\right)^{\mathrm{n}} /\left(\mathrm{T}_{\mathrm{ig}}-\mathrm{T}_{\mathrm{a}}\right)\left(\mathbf{k \rho c} \mathrm{c}_{\mathrm{p}}\right)^{1 / 2}
$$


Table 4. Release rates of Polymer Vapors and Heat, Heat of Combustion and Yields of Products in the Combustion of Polymers

\begin{tabular}{|c|c|c|c|c|c|c|c|}
\hline \multirow[t]{2}{*}{ Polymer } & \multirow[t]{2}{*}{ Lab } & \multirow{2}{*}{$\dot{\mathrm{m}}_{\mathrm{kg} / \mathrm{m}^{2}-\mathrm{s}} \mathbf{1 0}^{3}$} & \multirow{2}{*}{ 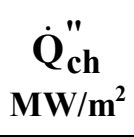 } & \multirow{2}{*}{$\begin{array}{c}\Delta \mathbf{H}_{\mathrm{ch}} \\
\mathbf{M J} / \mathbf{k g}\end{array}$} & \multicolumn{3}{|c|}{$\begin{array}{l}\text { Yield } \\
\mathrm{kg} / \mathrm{kg}\end{array}$} \\
\hline & & & & & $\mathrm{CO}$ & $\mathrm{CO}_{2}$ & Sm \\
\hline \multirow{6}{*}{$\begin{array}{l}\text { POM } \\
\text { aliphatic: } \\
\text { C, H, O } \\
\text { M= 29 } \\
\text { g/mole }\end{array}$} & INERIS & 52 & 0.75 & 15.1 & 0.002 & 1.46 & 0.001 \\
\hline & FMR-1 & 39 & 0.59 & 15.2 & 0.001 & 1.47 & 0.001 \\
\hline & FMR-2 & 43 & 0.66 & 15.4 & 0.001 & 1.49 & 0.001 \\
\hline & Average & 44 & 0.67 & 15.2 & 0.001 & 1.47 & 0.001 \\
\hline & \multicolumn{3}{|c|}{ Combustion Efficiency } & 0.97 & & & \\
\hline & \multicolumn{4}{|c|}{ Generation Efficiency } & 0.001 & 0.969 & 0.002 \\
\hline \multirow{6}{*}{$\begin{array}{l}\text { PMMA } \\
\text { aliphatic: } \\
\mathrm{C}, \mathrm{H}, \mathrm{O} \\
\text { atoms } \\
\mathrm{M}=100 \\
\text { g/mole }\end{array}$} & INERIS & 84 & $1.81^{\mathrm{a}}$ & $21.6^{\mathrm{a}}$ & $0.050^{\mathrm{a}}$ & $1.94^{\mathrm{a}}$ & $0.022^{\mathrm{a}}$ \\
\hline & FMR-1 & 80 & 1.83 & 23.0 & 0.012 & 2.02 & 0.030 \\
\hline & FMR-2 & 78 & 1.80 & 23.2 & 0.024 & 2.03 & 0.022 \\
\hline & Average & 81 & 1.82 & 22.8 & 0.018 & 2.00 & 0.025 \\
\hline & \multicolumn{3}{|c|}{ Combustion Efficiency } & 0.92 & & & \\
\hline & \multicolumn{4}{|c|}{ Generation Efficiency } & 0.013 & 0.912 & 0.038 \\
\hline \multirow{6}{*}{$\begin{array}{l}\text { Nylon 6,6 } \\
\text { aliphatic: } \\
\mathrm{C}, \mathrm{H}, \mathrm{O}, \mathrm{N} \\
\text { atoms } \mathrm{M}= \\
226 \mathrm{~g} / \mathrm{mole}\end{array}$} & INERIS & 46 & 1.21 & 23.8 & 0.026 & 2.04 & 0.037 \\
\hline & FMR-1 & 56 & 1.53 & 24.0 & 0.017 & 2.06 & 0.058 \\
\hline & FMR-2 & 54 & 1.54 & 25.0 & 0.029 & 2.14 & $\mathrm{~b}$ \\
\hline & Average & 52 & 1.43 & 24.3 & 0.024 & 2.08 & 0.048 \\
\hline & \multicolumn{4}{|c|}{ Combustion Efficiency } & & & \\
\hline & \multicolumn{4}{|c|}{ Generation Efficiency } & 0.015 & 0.825 & 0.080 \\
\hline \multirow{6}{*}{$\begin{array}{l}\text { PVC } \\
\text { aliphatic: } \\
\text { C,H,Cl } \\
\text { atoms } \\
\mathrm{M}=62 \\
\text { g/mole }\end{array}$} & INERIS & 20 & 0.16 & 7.9 & 0.086 & 0.551 & 0.094 \\
\hline & FMR-1 & 21 & 0.17 & 8.2 & 0.071 & 0.570 & 0.128 \\
\hline & FMR-2 & 28 & 0.20 & 7.8 & 0.091 & 0.520 & 0.116 \\
\hline & Average & 23 & 0.18 & 8.0 & 0.083 & 0.55 & 0.113 \\
\hline & \multicolumn{3}{|c|}{ Combustion Efficiency } & 0.42 & & & \\
\hline & \multicolumn{4}{|c|}{ Generation Efficiency } & 0.079 & 0.372 & 0.323 \\
\hline \multirow{6}{*}{$\begin{array}{l}\text { PC } \\
\text { aromatic: } \\
\mathrm{C}, \mathrm{H}, \mathrm{O} \\
\text { atoms } \\
\mathrm{M}=\mathbf{2 3 8} \\
\mathrm{g} / \mathrm{mole} \\
\end{array}$} & INERIS & 23 & 0.43 & 18.9 & 0.046 & 1.73 & 0.117 \\
\hline & FMR-1 & 31 & 0.51 & 17.1 & 0.032 & 1.57 & 0.146 \\
\hline & FMR-2 & 28 & 0.49 & 18.3 & 0.049 & 1.67 & 0.086 \\
\hline & Average & 27 & 0.48 & 18.1 & 0.042 & 1.66 & 0.116 \\
\hline & \multicolumn{3}{|c|}{ Combustion Efficiency } & 0.60 & & & \\
\hline & \multicolumn{4}{|c|}{ Generation Efficiency } & 0.024 & 0.594 & 0.142 \\
\hline \multirow{6}{*}{$\begin{array}{l}\text { PSF } \\
\text { aromatic: } \\
\text { C,H,O,S } \\
\text { atoms } \\
\mathrm{M}=\mathbf{4 4 2} \\
\mathrm{g} / \mathrm{mole} \\
\end{array}$} & INERIS & 20 & 0.44 & 17.2 & 0.045 & 1.59 & 0.098 \\
\hline & FMR-1 & 20 & 0.45 & 17.2 & 0.079 & 1.59 & 0.079 \\
\hline & FMR-2 & 22 & 0.39 & 16.5 & 0.085 & 1.52 & 0.085 \\
\hline & Average & 21 & 0.43 & 17.0 & 0.070 & 1.57 & 0.087 \\
\hline & & Combustior & fficiency & 0.56 & & & \\
\hline & \multicolumn{4}{|c|}{ Generation Efficiency } & 0.040 & 0.543 & 0.119 \\
\hline
\end{tabular}

a: slightly under-ventilated conditions due to extremely high burning rate at $50 \mathrm{~kW} / \mathrm{m}^{2}$. $\mathrm{CO}$ is unusually high and heat release rate, heat of combustion, and $\mathrm{CO}_{2}$ and smoke yields are low; b: data not recorded properly. 
Based on the correlation between small-scale and large-scale upward fire propagation experiments, Eq 5 is modified as follows [16,17]:

$$
\mathbf{v}^{1 / 2} \propto\left[\left(\chi_{r} / \chi_{c h}\right) \dot{Q}_{c h} / w\right]^{1 / 3} /\left(T_{i g}-T_{a}\right)\left(k \rho c_{p}\right)^{1 / 2}
$$

Multiplying Eq. 6 by 1000 and assuming $\chi_{\mathrm{r}} / \chi_{\mathrm{ch}} \approx 0.42$, a Fire Propagation Index (FPI) has been defined to describe the large-scale vertical fire propagation behaviors of polymers based on small-scale test measurements $[8,9,17]$ :

$$
\mathrm{FPI}=1000\left(\left(0.42 \dot{\mathrm{Q}}_{\mathrm{ch}} / \mathrm{w}\right)^{1 / 3} /\left(\mathrm{T}_{\mathrm{ig}}-\mathrm{T}_{\mathrm{a}}\right)(\mathrm{k} \rho \mathrm{c})^{1 / 2}\right)=750\left(\dot{\mathrm{Q}}_{\mathrm{ch}} / \mathrm{w}\right)^{1 / 3} /\left(\mathrm{T}_{\mathrm{ig}}-\mathrm{T}_{\mathrm{a}}\right)(\mathrm{k} \rho \mathrm{c})^{1 / 2}
$$

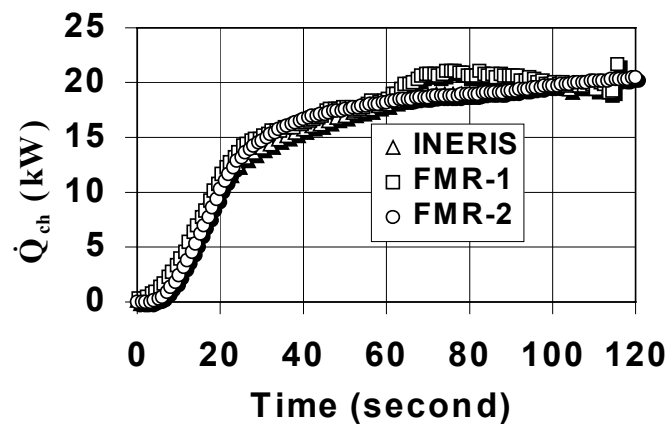

Figure 6. Heat release rate profile for the upward fire propagation at $40 \%$ oxygen concentration for PMMA.

The $\dot{\mathbf{Q}}_{\text {ch }}$ values from the fire propagation experiments and the $\left(\mathbf{T}_{\mathbf{i g}}-\mathbf{T}_{\mathbf{a}}\right) \sqrt{\mathbf{k} \rho \mathbf{c}}$ values, defined as TRP, from the ignition experiments are used in Eq. 7 to calculate the FPI values. Based on the visual observations in small-scale and largescale fire propagation experiments, the following behaviors have been observed [8,9, 16,17]:

1) For FPI $\leq$ 6: flames are close to extinction conditions and fire propagation is limited to the ignition zone (area where surface is exposed to external heat flux in the presence of a pilot flame);

2) For $6<\mathrm{FPI} \leq 10$ : fire propagation is decelerating and stops short of the sample length;

3 ) For $10<\mathrm{FPI} \leq 20$ : there is fire propagation beyond the ignition zone;

4) For FPI > 20: fire propagation beyond the ignition zone is very rapid.

Excellent correlation has been found between the FPI values from the smallscale and large-scale tests $[8,9,17]$. The FPI concept thus has been adopted for the acceptance of polymers in the clean rooms of the semi-conductor industry by FM Approvals and Underwriters Laboratories (UL) [18,19], and for electrical cables and conveyor belts by FM Approvals [20,21]. Thus, we have also used the FPI concept in this study to describe the fire propagation behaviors of the selected polymers.

Since there is an excellent agreement between the three laboratories for the heat release rate profiles and TRP values, FPI values from the three laboratories also show excellent agreement as indicated in Fig. 7.

The FPI value of PMMA (23) suggest rapid propagation that is confirmed by the data from the large-scale parallel tests $[9,17]$ and many large-scale vertical wall fires $[22,23,24]$. The FPI value for POM is 13 for which fire propagation was observed to be rapid. For char forming polymers (PC and PSF) and halogenated polymer (PVC), the

The FPI values were in the range of 6.9 to 8.4 , for which fire propagation was observed to be either slow or decelerating. Thus, all the factors that influence the 
variations in the ignition and combustion behaviors of polymers are also responsible for the differences in the fire propagation behavior.

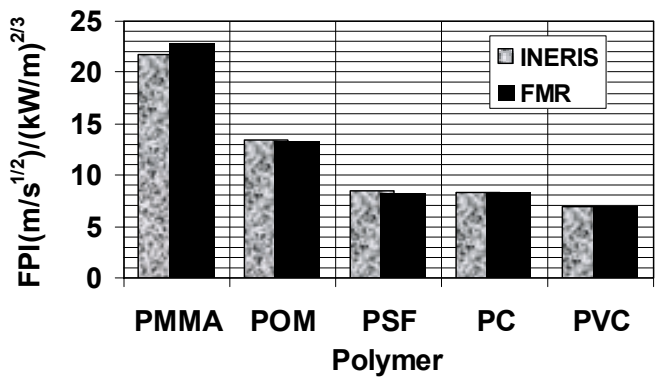

Figure 7. Fire Propagation Indices for Polymers.

\section{SUMMARY}

1) Under similar experimental conditions, differences in the ignition, combustion, and fire propagation behaviors of polymers are found to be influenced by the generic nature and molecular weight of the monomer;

2) Ignition temperature appears to be the main factor affecting differences in the ignition

behavior of polymers. The $\sqrt{\mathbf{k \rho c}}$ values are weakly dependent on the generic nature of the polymers. About $25 \%$ of the ignition resistance is due to differences in the generic nature of the polymers;

3) The combustion efficiency and generation efficiency of $\mathrm{CO}_{2}$ decrease and the generation efficiencies of $\mathrm{CO}$ and smoke increase as the generic nature of polymers changes from aliphatic to aromatic to halogenated. The combustion efficiency and generation efficiencies of products are closely related. A direct linear relationship is found between the generation efficiencies of $\mathrm{CO}$ and smoke, whereas an inverse nonlinear relationship is found between the generation efficiency of $\mathrm{CO}_{2}$ and that of $\mathrm{CO}$ and smoke;

4) About four times of the carbon atoms in the polymer are converted to smoke than to $\mathrm{CO}$;

5) Generation rate of vapors for polymers that burn as solids is well predicted from the heat of gasification and surface reradiation loss at high external heat flux values where flame heat flux is negligibly small. The generation rate of vapors for polymers that burn as liquid pool fires however is under-predicted, suggesting that heat of gasification values for liquids rather than that of solid polymers need to be used.

6) Large-scale fire propagation behavior of polymers is well characterized by a Fire Propagation Index (FPI). Melting type ordinary thermoplastics have high FPI values and have been observed to have rapid-fire propagation. The FPI values for the engineered charring type and halogenated polymers are low and have been observed to have either slow or decelerating fire propagation beyond the ignition zone.

\section{ACKNOWLEDGEMENTS}

The financial support provided for this work (as part of the evaluation of the INERIS FPA) by the French Ministry for Land Use Planning and the Environment is gratefully acknowledged by one of us (GM).

\section{NOMENCLATURE}

c Heat capacity $(\mathrm{kJ} / \mathrm{kg}-\mathrm{K})$

$\mathbf{f}_{\mathbf{j}} \quad$ Generation efficiency of product $\mathrm{j}$

$\dot{\mathbf{G}}_{\mathbf{j}} \quad \quad$ Generation rate of product $\mathrm{j}$ per unit polymer surface area $\left(\mathrm{kg} / \mathrm{m}^{2}-\mathrm{s}\right)$ 


$\begin{array}{ll}\Delta \mathbf{H}_{\mathbf{i}} & \text { Heat of combustion of the polymer }(\mathrm{MJ} / \mathrm{kg}) \\ \Delta \mathbf{H}_{\mathbf{g}} & \text { Heat of gasification of the polymer }(\mathrm{MJ} / \mathrm{kg}) \\ \mathbf{k} & \text { Thermal conductivity }(\mathrm{W} / \mathrm{m}-\mathrm{K}) ; \\ \dot{\mathbf{m}}^{\prime \prime} & \text { Release rate of polymer vapors per unit polymer surface area }\left(\mathrm{kg} / \mathrm{m}^{2}-\mathrm{s}\right) \\ \mathbf{M}_{\text {mono }} & \text { Molecular weight of the monomer }(\mathrm{g} / \mathrm{mole}) \\ \dot{\mathbf{q}}_{\mathbf{i}}^{\prime \prime} & \text { Heat flux per unit polymer surface area }\left(\mathrm{kW} / \mathrm{m}^{2}\right) \\ \dot{\mathbf{Q}}_{\mathbf{c h}}^{\prime \prime} & \text { Chemical heat release rate per unit polymer surface area }\left(\mathrm{kW} / \mathrm{m}^{2}\right) \\ \mathbf{t}_{\mathbf{i g}} & \text { Ignition-time }(\mathrm{s}) \\ \mathbf{T} & \left.\text { Temperature }{ }^{\circ} \mathrm{C}\right) \\ \mathbf{V} & \text { Upward fire propagation velocity }(\mathrm{m} / \mathrm{s}) \\ \mathbf{W} & \text { Sample width }(\mathrm{m}) \\ \mathbf{y}_{\mathbf{j}} & \text { Yield of product } \mathrm{j}(\mathrm{g} / \mathrm{g}) \\ \text { Greek } & \\ \chi & \text { Combustion efficiency } \\ \rho & \text { Density }\left(\mathrm{kg} / \mathrm{m}^{3}\right) \\ \text { Subscripts } & \text { Ambient } \\ \mathbf{a} & \text { Chemical } \\ \mathbf{c h} & \text { Critical } \\ \mathbf{c r} & \text { Decomposition } \\ \mathbf{d} & \text { External } \\ \mathbf{e} & \text { Re-radiation } \\ \mathbf{r r} & \text { Total or Complete } \\ \mathbf{T} & \text { Vaporization } \\ \mathbf{V} & \end{array}$

\section{REFERENCES}

1. Physical Properties of Polymers Handbook, J.E. Mark (Editor), American Institute of Physics, Woodbury, New York, 1996.

2. ASTM E 2058-00, The American Society for Testing and Materials, West Conshohocken, PA. February 10, 2000

3 Marlair, G., and Tewarson, A., Interflam'01-Ninth International Fire Science and Engineering Conference (Proceedings pp. 1255 to 1260).

4. Domininghaus H., Plastics for Engineers-Materials, Properties, Applications. Hanser Publishers. New York, NY. 1988.

5. Abu-Isa, I.A., Cummings, D.R., and LaDue, D., " Thermal Properties of Automotive Polymers I. Thermal Gravimetric Analysis and Differential Scanning Calorimetry of Selected Parts from a Dodge Caravan", Report R\&D 8775, General Motors Research and Development Center, Warren, MI, June, 1998.

6. Abu-Isa, I. A., “ Thermal Properties of Automotive Polymers II. Thermal Conductivity of Parts Selected from a Dodge Caravan", US National Highway Traffic Safety Administration Docket Number NHTSA-1998-3588-39, March 29,1999 .

7. Handbook of Plastics and Elastomers, Harper, C.A. (Editor), McGraw-Hill Book Company, New York, N.Y. 1975. 
8. Tewarson, A., SFPE Handbook of Fire Protection Engineering, Section 3, Chapter 4, pp. 3-53 to 3-124. The National Fire Protection Association Press, Quincy, MA. 1995.

9. Tewarson., Chapter 12 in Polymers and the Environment-A Handbook, A.L. Andrady (Editor), to be printed in 2002.

10. Quintiere, J.G., SFPE Handbook of Fire Protection Engineering, Section 2, Chapter 14, pp. 2-205 to 2-216. The National Fire Protection Association Press, Quincy, MA. 1995.

11. Tewarson, A., Abu-Isa, I.A., Cummings, D.R., and LaDue, D.E., Fire Safety Science, Proceedings of the Sixth International Symposium, pp. 991-1002, University of Poitiers, France, 5-9 July, 1999.

12. Tewarson, A., "Flammability Properties of Engine Compartment Fluids Part I. Combustion Properties of Fluids Containing Carbon, Hydrogen, and Oxygen", Technical Report OB1R7.RC (1998), FM Global Research, Norwood, MA. August 1998.

13. Ohlemiller, T.J., and Shields, J.R., "Burning Behavior of Selected Automotive Parts from a Minivan", US National Highway Traffic Safety Administration Docket Number NHTSA-1998-3588-26, December 02, 1998.

14. Tewarson, A., Lee, J.L., and Pion, R.F., Eighteenth Symposium (International) on Combustion, pp. 563-570. The Combustion Institute, Pittsburgh, PA. 1981.

15. Fernandez-Pello A.C., and Hirano, T., Combustion Science and Technology, 32, 1-31,1983.

16. Tewarson, A., and Khan, M.M., Twenty-Second Symposium (International) on Combustion, pp. 1231-1240. The Combustion Institute, Pittsburgh, PA. 1988.

17. Tewarson, A., Khan, M. M., Wu, P. K. S., and Bill, R. G., J. Fire and Materials, 25, 31-42, 2001.

18. FM Approvals Test Standard 4910, "Clean Room Materials Flammability Test Protocol”, Factory Mutual Research, Norwood, MA, September 1997.

19. UL 2360, "Standard Test Method for Determining the Combustibility Characteristics of Plastics Used in Semiconductor Tool Construction", Underwriters Laboratory, Northbrook, IL. 2000.

20. Specification Standard for Cable Fire Propagation, Class 3972, FM Approvals, Norwood, MA, 1989.

21. Approval Standard, Class 1 Conveyor Belting, Class No. 4998, FM Approvals, Norwood, MA, 1995.

22. Orloff, L., de Ris, J., and Markstein G., Fifteenth Symposium (International) on Combustion, pp.183-192. The Combustion Institute, Pittsburgh, PA. 1974.

23. Orloff, L., Modak, A.T., and Alpert, R.L., Sixteenth Symposium (International) on Combustion, pp.1345-1354. The Combustion Institute, Pittsburgh, PA. 1976.

24. Quintiere, J.G., Harkleroad, M,, and Hasemi Y., Combustion Science and Technology, 48, 191-222, 1986. 